\title{
The effect of Quran murottal's audio on short term memory
}

\author{
Perdana Suteja Putra, Retno Gumilar, Sasmita Rahma Kusuma*, Hari Purnomo, and Chancard Basumerda \\ Islamic University of Indonesia , Jalan Kaliurang Km. 14,5 Sleman, Yogyakarta, Indonesia
}

\begin{abstract}
In all activities, people need memory as information storage. A good memory will make it easier for people to remember so they can do their job well. One of the things that affect memory is the sound of music. Music is commonly used as a stress treatment or as one of the stimuli of human brain memory. Not only classical music can be one of the stimuli of brain memory, but listening to the Quran can also be one of the brain memory stimulants. Several studies have proven that by listening to the Qur'an, the ability of the brain can be increased significantly. In this study used the variables pre and posted Qur'an listening to 50 respondents. Respondents consisted of 26 men and 24 women aged 19-22 years old. All respondents will get two treatments. The first treatment is without listening to murottal and the second treatment is done after listening to the Quran. All respondents will do memory test using the program running memory in software design tools. The results showed that the average ability of short-term memory without listening to murottal 11.8 and the average ability of short-term memory by listening to murottal is 12.62 . Based on these results it is known that by listening to the Quran provides a significant increase in the ability of the brain.
\end{abstract}

\section{Introduction}

In carrying out daily work, human beings need memory to store information. Good memory performance will make it easier for people to remember so that work can be completed faster and minimize errors [1]. The performance of memory is not only be influenced by body condition and human health, but also influenced by work environment factor. Therefore, the environment and working atmosphere must be designed in such a way as to support better memory performance.

Based on the duration and level of use, memory is divided into two, namely long-term memory and shortterm memory. Long term memory is a memory that is often used and stored up to a long time even up to years. While short-term memory only shortly after the information obtained, without any repetition of the information. The information will be lost in maximum time after 30 seconds (Xu, 2002). In addition, the amount of information that can be stored is limited. The amount of information that can be stored by short term memory is $7+2$ units [2]. Based on the above explanation, short term memory needs to be considered its performance because of its easy to lose in a short time.

So to optimize the work performance, need to note the state of the physical work environment. One of the physical work environments that can affect performance is sound. Various sources of sound can be a stimulus for someone in work, one of which is music. Music is sound, a collection of musical instruments, and a combination of sound and musical instruments that produce harmony, melody, and rhythm. Music is widely used for the treatment of stress or as one of the brain memory stimulants. Not only classical music can be one of the brain's memories stimulants. Several studies have shown that reading the verses of the Qur'an can also provide a good stimulus for the brain. In addition, there is a stigma in the community that by reading or listening to the verses of the Quran can be a drug stress and improve the ability of the brain.

A study was conducted on four respondents using two different treatments. After a memory test using a free recall test, respondents in the experimental group were recited by the Qur'an for 15 minutes. While the respondents in the control group received a placebo treatment of reading the story of the animal world. Then all the respondents performed a memory test again. The results obtained by the experimental group experienced significant improvement in memory capacity after treatment. While the control group there was no significant difference between before and after treatment [3]. Research from Abdurrochman, Perdana, and Andhika shows when listening to the Qur'an occurs a significant rise in brainwaves before and after the Al-Quran [4]. Therefore, researchers conducted research on the effect of murattal Quran on short-term memory performance.

\section{Literature Review}

\subsection{Short-Term Memory}

Short-term memory has a small capacity, but a very large role in the memory process, which is where we process the stimuli that come from our environment. This small information storage capability corresponds to a limited 
processing capacity. Short-term memory serves as a transitory storage that can store very limited information and transform and use that information to produce a response to a stimulus [8].

Sensory memory records information or stimuli that enter through one or a combination of the five senses, i.e., visually through the eyes, ear hearing, smell through the nose, taste through the tongue, and touch the skin. If the information or stimuli are not noticed will be immediately forgotten, but when noted then the information is transferred to the short-term memory system. Short-term memory systems store information or stimuli for about 30 seconds, and only about seven chunks of information (chunks) can be stored and maintained in short-term memory systems at a time. Once in the short-term memory system, the information can be transferred again by repetition process to the long-term memory system for storage, or it may be lost/forgotten because it is replaced by additional displacement [5].

The temporal dynamics of the embedded component model are being mapped out in the behavioral literature. For example, memory items that are no longer relevant for behavior can be removed (within 1-2 sec) from the focus of attention, thereby reducing the load on the system's limited capacity and consequently reducing reaction time to memory probes of the behaviorally relevant items still in the focus [6]. Information removed from the focus remains in a state of heightened availability for several seconds, as shown by the finding that lures from a recently encoded memory list are harder to reject than lures not recently encountered [6]. This information can be refocused if needed again otherwise, it is prone to forgetting by decay or by interference [7].

\subsection{Holy Qur'an}

The Qur'an is a holy book of Muslims. According to the Islamic ummah is the revelation of the God revealed to the prophet Muhammad 14 centuries ago by the mediation of the angel Gabriel. The Qur'an consists of 114 chapters called letters. Each letter consists of various verses with different amounts. Muslims say that in the Qur'an contains important information that can provide answers and solutions to the problems facing humans [9].

Hawari (1997) [10] mentions that many Qur'anic verses contain the guidance of how humans in life in this world free from anxiety, tension, and depression. Research conducted by Chalfant and Heller in Hawari (1997) showed $40 \%$ of people who experience mental anxiety are brought to religious experts for treatment. Also in the Qur'an also found verses about the peace Research from a doctor in Florida named Qadhi found that when reading the verses of the Quran, it will feel the serenity [3].

\section{Research Method}

\subsection{Subject and Object Experiment}

a. Subject Experiment
There were 50 university students (26 male and 24 female) in the range of 19 to 22 years old was appointed to be the subject of this research. Assuming each participant has the same understanding of the ability of the experiment, in this case, is the short term memory.

b. Object Experiment

Short term memory testing using software design tools. One of the components contained in this software is a program running memory task. Running memory task program is a program used for short-term memory testing. In this program a sequence of numbers will appear for a few seconds, then disappears. After that will be shown a dialog box to enter a sequence of numbers that appear earlier.

\subsection{Research Procedure}

a. Preparation

In this step, researchers prepared needed apparatus to do the short term memory test performance influenced by murottal. Apparatus were used in this research are notebook Toshiba 11", handsfree, design tools software and experimental room.

b. Experimental Design

Respondents will perform two experimental conditions. In the first condition, participants do the tests given without listening to murrotal. After working on the first experiment, participants were given a chance to rest for a few minutes. Then participants will experiment as before along with listening to murrotal juz amma. The correct numerical answer data is used as a measurement parameter. This is done 15 times using the Design Tools software to test the respondents.

c. Data analysis

The method used in this study is the experimental method, because according to its importance the experimental method is used to find out the cause [11] and to know there is no effect of listening murrotal to the ability of short-term memory. Data processing in this research using paired sample t-test with a confidence level $95 \%$.

Hypothesis :

Ho $=$ There are no difference in the average short term memory between pre and post listening murottal.

$\mathrm{H} 1=$ There are an difference average of short term memory between pre and post

listening murottal.

\section{Result and Discussion}

The results of this study used to determine the effect of the murattal Quran on the ability of short-term memory. Data obtained from the testing of short-term memory performance using Design Tools software. 
Correct Answer

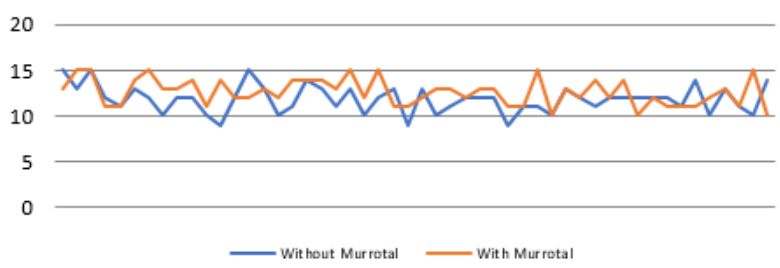

Figure 1. Result of the Experiment

From 15 experiments, the graph shows that there is a difference in experimental results when were not listening to murattals and when were listening to murattals. Respondents who listened to murattals during the experiment conducted, having good concentration. So it can remember and reply the numbers displayed correctly. While respondents who did not listen to murattals during the experiment, had low concentrations. This resulted in only part of the correct answer.

Data were analyzed using statistical analysis paired sample t-test. During the test, found that there was a difference between the two treatments in the experiments performed. Based on the results of paired sample t-test shows there are differences caused by the use of murattal. The test was performed using IBM SPSS software version 22 , with the following results.

Table 1. Result of the paired samples test

\begin{tabular}{|c|c|c|c|c|c|c|c|}
\hline & \multicolumn{3}{|c|}{ Paired Differences } & \multirow[b]{2}{*}{$\mathrm{T}$} & \multirow[b]{2}{*}{ df } & \multirow[b]{2}{*}{$\begin{array}{l}\text { Sig. (2- } \\
\text { tailed) }\end{array}$} \\
\hline & & Mean & $\begin{array}{c}\text { Std. } \\
\text { Deviation }\end{array}$ & $\begin{array}{l}\text { Std. } \\
\text { Error } \\
\text { Mean }\end{array}$ & & & \\
\hline $\begin{array}{c}\text { Pair } \\
1\end{array}$ & \begin{tabular}{|c} 
With \\
Murottal - \\
Without \\
Murottal
\end{tabular} & 0.82 & 1.945 & 0.275 & 2.981 & 49 & 0.004 \\
\hline
\end{tabular}

From the result of Paired Sample T-test, the decision were taken based on the significant value. The data shows that the Sig Value $<0.05$ is 0.004 so that Ho is rejected. The result showed that there is a difference in the average value of short-term memory between pre and post murattal listening. It proved after the respondents listening to the murottal, and the concentration will be increase. This is supported by [12], which has conducted a study to find out whether music can enhance the ability of people with Alzheimer's to recognize the nurse face according to the name of the nurse. This study used two treatments, there are with and without the music. The results showed that four out of seven subjects get better results when using music.

Another alternative besides music therapy according to [13] is a religious therapy. Religious therapy can be an accelerated healing, as evidenced by various experts has been done by Ahmad Al Qadi, managing director of Islamic Medicine Institute for Education and Research in Florida, USA. The results of these studies showed positive results that listen to the Qur'an has a significant effect in reducing a nervous tension [13]. Holy verses of the Qur'an have a therapeutic effect in reading and listening [14]. Murattal and music therapy works on the brain, which driven by external simultaneous, then the brain will produce a chemical called neuropeptide. These molecules will be hooking into their receptors in the body and will provide feedback in the form of pleasure or comfort [15]. Based on some opinions above, it can be concluded that listening to Holy Qur'an can give comforts to people who could be a stimulant to increasing people concentration level.

The authors thank to all parties for sponsoring and facilitating this research, and also for all respondents in this research.

\section{References}

1. Xu Y. Limitation of Object-Based Feature Encoding in Visual Short Term Memory. http://www.sciencedirect.com, [online, accesed 19 March 2010]. (2002).

2. Miller G., A. The Magic Number Seven plus-minus Two: Some Limits on Our Capacity to Process Information. Psychological Review, 63, pp 81-97. (1956).

3. Julianto V., \& Etsem, M., B. The Effect of Reciting Holy Qur'an toward Short-term Memory Ability Analysed trought the Changing Brain Wave. Jurnal Psikologi Fakultas Psikologi Universitas Gajah Mada. (2011).

4. Abdurrochman A., P. Muratal Al Quran : Alternatif Terapi Suara Baru. Prosiding Seminar Sains dan Teknologi-II. (2008).

5. Solso R.,L. Cognitive Psychology. (4th ed). Boston: Allyn and Bacon, Inc. (1995).

6. Oberauer, K. Removing irrelevant information from working memory: A cognitive aging study with the modified Sternberg task. Journal of Experimental Psychology: Learning, Memory, \& Cognition, 27, 948-957. (2001).

7. Oberauer, K. Control of the contents of working memory-A comparison of two paradigms and two age groups. Journal of Experimental Psychology: Learning, Memory, \& Cognition, 31, 714-728. (2005).

8. Bhinnety M., Sugiyanto dan M. Pudjono. Pengaruh Intensitas Kebisingan Terhadap Memori Jangka Pendek. Jurnal Psikologi, XXI, 1, Juni, 28-38. (1994).

9. Firmanto A. Implementasi Principal Component Analysis Dan Backpropagation Neural Network Dalam Pengklasifikasian Terjemahan Ayat-Ayat Ilmu Pengetahuan Dalam Alquran. Tugas Akhir. Telkom University. (2011).

10. Hawari D. Al-Qur'an Ilmu Kedokteran Jiwa dan Kesehatan Jiwa. Yogyakarta: PT. Dana Bhakti Yasa. (1997).

11. Akmal R. Pengaruh Pengulangan Terknik Permainan Olahraga Bola Basket Terhadap Peningkatan Kemampuan Motorik Kasar (Gross Motor) Anak Tunagrahita Ringan Usia Mental 5 - 9 Tahun. Universitas Pendidikan Indonesia. (2013). 
12. Carruth E. The Effects Of Singing And The Spaced Retrieval Technique On Improving Face-Name Recognition In Nursing Home Residents With Memory Loss. Journal of Music Therapy, 34, 165186. (1997).

13. Remolda P. Pengaruh Al-Quran pada Manusia dalam Perspektif Fisiologi dan Psikologi. http://www.theedc.com. (2009).

14. Oken B., S. Complementary Therapies in Neurology: An Evidence-Based Approach. USA:The Parthenon Publishing Group. (2004).

15. O'riordan R., N., L. Seni Penyembuhan Alami:Rahasia Penyembuhan Melalui Energi Ilahi diterjemahkan oleh Sulaiman Al-Kumaiyi dari judul asli The Art of Sufi Healing. Bekasi: Gugus Press. (2002). 